\title{
Institutions, Macroeconomic Policies and Economic Growth in Africa: Evidence from Panel Data
}

\author{
H. M. Aliero \\ Department of Economics, Usmanu Danfodiyo University Sokoto \\ E-mail: harliero66@yahoo.com \\ Muftau O. Olarinde \\ Department of Economics, Usmanu Danfodiyo University Sokoto \\ E-mail: Muftomi@yahoo.com; olarinde.muftau@udusok.edu.ng
}

Received: June 2, 2018 Accepted: October 22, 2018 Published: April 30, 2019

doi:10.5296/jad.v5i2.13421 URL: https://doi.org/10.5296/jad.v5i2.13421

\begin{abstract}
This study investigates the effects of institution and macroeconomic policy on economic growth in Africa, using panel Cointegration technique to analysed data obtained from a panel of 50 African Countries covering a period of 25years (1990-2014). The results confirm that declining growth rate in Africa is due to poor management of macroeconomic policies. A weak turning point is also confirmed to exist for government size in the short run; in the long run it becomes more pronounce. The Wald restrictions tests of causality ascertain that institutions lead economic growth performance in the short run, while poor economic growth performance impaired the capacity required in building strong institutions which in turn stunts growth in the long run. Therefore, African leaders should tilt their expenditure in favour of human capital development and strong institution, ensure intra-regional trade and adopt private sector led - economic growth strategy.
\end{abstract}

Keywords: panel cointegration, economic growth, Africa, Institution, causality, policy

JEL Classification: E02, H11, N4, N20

\section{Introduction}

In the 1960s, it was widely argued that long-term economic performance depended on accumulation of capital (Rosenstein-Rodan, 1943) and that increasing savings through heavy government intervention would propel countries into sustainable growth (Rostow, 1960). In 
the early 1980s, achievements of growth devoid of volatility were hinged on the importance of a good policy framework (Williamson, 1975; World Bank, 1993). In recent times particularly in the early 2000s, the literature emphasized that these policies would have only minimal effects if quality institutional reforms are missing (World Bank, 1998).

In Africa, the challenges of economic development have remained frightening. In spite of the numerous economic strategies and measures implemented over the year, a desirable economic growth which is both inclusive and sustainable has remained elusive. With the presence of abundant resources, yet the region finds it difficult to win the war against poverty, unemployment and inequality. The conclusion therefore, is that even though resources are imperative for growth, there availability alone does not entail a sufficient condition for growth, but requires good management and governance (Obadan, 2009).

Several macroeconomic indicators support the fact that African countries experienced increased growth rates due to good policy design leading to macroeconomic stability (Chukwuma and Aldo, 2013). For instance, the region's output growth rate that was 2.7 percent in the $1980 \mathrm{~s}$ declined to 2.6 percent in $1990 \mathrm{~s}$ and jumped to 4.5 percent in the $2000 \mathrm{~s}$, above the world's average growth rate of 3.3 in the same period (World Bank, 2013).

However, the growth rate is unsustainable despite the fact that it is positive. For instance, between 2000 and 2011 the growth rate was $9.61 \%$ in 2004 and declined to $4.38 \%$ in 2011 (World Bank, 2013). Thus, the unsustainable growth pattern in the entire sub-Shara region despite a series of macroeconomic policies introduced alongside different structural reforms portrays s a mixing link between the policy designs and the economic performance of African economies.

Several authors have argued that the slow growth rate associated with African economies could be alluded to the peculiar nature of its environment, while others have argued that the unsustainable nature of Africa's macroeconomic outcomes is a mirror image of her weak institutions (Sachs and Warner, 1997; Acemoglu et al., 2003a; Easterly and Levine, 2001; Guisan, 2009; Mahmud, 2009; Jayanti and Sushit Kr, 2015; Barro, 2013). As robust as most of these empirical studies are, they have not exploited the nature of relationship among these growth fundamentals in the short run as well as the direction of causality among the variables. Again, their empirical results, suggest that policies and institutions have non-linear relations on growth. For instance, the provision for property rights, government size, inflation etc. are good examples of institutional and policy indicators that at a certain rate it become absolutely important for growth to occur, but can hurt growth in greater doses (Chang, 2011).Therefore, drawing conclusions from the estimates of linear equations when the impacts of independent variables are non-linear is bound to generate erroneous conclusions (Ros, 2013). In this regard, this study empirically investigates the impact of institutions and policy effectiveness on economic growth in Africa using a non-linearity approach.

The paper is divided into 5 sections, aside section 1, which serves as background to the study. Section 2 dwells on review of both empirical and theoretical literature while section 3 entails sources of data and method of data analysis. Section 4 presents data analysis and interpretation of results and the paper concludes with recommendation in section 5 . 


\section{Review of Literature}

Institutions and policy effectiveness are critical in achieving the desired economic performance not only in Africa but also in the entire world. However, the level of growth matters and varies across countries. Institution can be conceptualised to be constraints that guide the conduct and behaviour of individual economic being. These constraints entail official rule purposely established to ensure existence of property rights and enforcement of contract (North, 1991; Acemoglu, Johnson and Robinson, 2000; Fukuyama, 2008; Ekpo, 2013). Thus, macroeconomic policy designs situated within a good institutional framework determines the economic performance of any nation.

Endogenous growth theories suggests that as far as the efficiency parameter in the Cobb Douglas growth model remain constant; continuous accumulation of capital will continue to result into increasing growth in output. This is predicated on the belief that the technological knowledge obtained through R\&D entails positive spill over effect which allow social benefits to be over and above private benefits. Therefore, aggregate stock of capital would not be subject to diminishing returns because of the increasing rate of investment in technology (Lucas, 1988; Romer, 1991). Capital entails not only physical capital but also human capital in form of acquisition of technological knowledge through research and development (R\&D). The higher rate of return on capital will have a multiplier effects on saving which in turn increases total output (Perman \& Stern, 2003).

Essentially, the allocation of saving to $R \& D$ to accumulate technological knowledge that necessitates increase in output is not automatic but depends largely on the quality of institutions and macroeconomic policies. Good institutional structures provide confidence to investors and protect them against problems of market failure associated with innovations (Stern, 2004).

Empirical studies focussing on the factors responsible for differences in growth rate of countries (most of which have been done using growth accounting framework) are abound, while some have found differences in total factor productivity (TFP) as an explanation for the differences in growth rates (Abranmoviz, 1956; Solow,1957; Denison, 1967; Jorgenson,1987; Jens, Bassanini and Scarpetta, 2011) others find differences in the quality of human and physical capital to be responsible for the differences in growth among countries (Young, 1994; Easterly et al., 1993; Krugman, 1994; Temple, 2001; Gennaioli et al., 2014). Yet some empirical results tend to lend support to the view that TFP, human capital and physical capital all combine in explaining the growth rate of an economy (e.g., Mankiw, 1992; Dougherty, 1996). For instance, Jens et al., (2011), using pool mean group (PMG) as method of data analysis with a sample of 21 OECD countries over past three decades, carried out an empirical study to validate the augmented Solow model or the Uzawa-Lucas model. The regression results reveal that both investment rate and human capital exert a positive impact on growth rate. Gennaioli et al., (2014) using sample data collected from 1,528 regions from 83 countries to compare the speed of per capita income convergence within and across countries, the result shows that regional growth is largely influenced by similar factors that account for national growth, such as geography and human capital. 
In an elaborate study, Kui-Wai Li et al. (2011) carried out an investigation on the absolute and conditional convergence of real GDP per capita among 164 world economies over the sample period 1970-2006 using nonparametric and semi parametric models. The empirical results show that the coefficients of the five control variables (investment, carbon dioxide, trade openness, life expectancy and foreign direct investment) have positive significant effects on the speed of growth convergence. On the contrary, government consumption, urbanization, inflation and private credit share, have a negative impact on economic growth.

Ouechtati et al. (2013) examine the co-movements of some economic variables and explore the structural factors of macroeconomic volatility in developing and transition economies, using data for 44 countries for 1960-2010. The GMM estimation results indicate that government expenditures, consumption and GDP volatilities are major causes of macroeconomic volatility. The result further provides an empirical insight into the possibility of bi-directional causality between growth and policy volatility advanced by Rostein-Rodan (1943) in his theory of structural transformation.

For those in support of causality running from globalisation to growth, the empirical result of the study conducted by Leong (2007), using OLS panel data model on two countries, India and China, indicates that a policy of more openness in the economy has a positive multiplier effect on economic growth. Most literature examining the impact of exchange rates misalignments on economic growth submit that exchange rate misalignment mostly has contractionary effects on growth in output. For instance, an empirical investigation into the impact of exchange rate volatility on growth by Aghion et al., (2006) provides evidence that real exchange rate volatility has a significant impact on long-term rate of productivity growth, depending critically on the level of a country's financial development. Isard (2007) maintains that there is reasonably strong evidence that the alignment of exchange rates has a critical negative influence on the rate of growth of per capita output in low-income countries and consequently on Balance of Payment (BOP) difficulties. García- et al. (2013) carried out an empirical analysis of the main determinants of aggregate investment and level of output across countries grouped into OECD and non-OECD countries. Their fixed effect model result indicates that both in the OECD and non-OECD countries, government expenditure has a negative relationship with rate of investment in durables and consequently on output. Further in their study, they found that, the real effective exchange rate remains significant across board, dampening manufacturing sectors thus reducing output. Barro (2013) also investigates the relationship between inflation and economic growth using system equations, the result indicates price instability has a declining impact on the growth rate of real per capita GDP by $0.4 \%-0.6 \%$. Also, favourable public policies that ensure maintenance of rule of law and property rights, fewer distortions of private market, less unproductive government spending, and greater public investment in high -return areas- have a positive significant long run impact on growth .

Further on the relationship between institution and economic growth, Fosu (2013) in an Africa study concludes that, qualitative institution which ensures binding constraints on the executive branch of government improve growth through a declining prevalence of adverse redistribution, inefficient allocation and state breakdown. Also, in a democratic regime, there 
is less corruption, but greater risk of conflict, from resource rents. He recommends that distributing the rents to the public might provide a solution to the resource-curse problems. Using GMM techniques on a panel of African countries, Siddiqui (2009) result suggests a strong causal link between institutional quality and economic performance. In relation to policy variables, it is confirmed that overall significance of macroeconomic policy variables (inflation, saving, public investment) improved as institutional variable is introduced into model. Hence, pursuing policies of inflation-financed growth might not be fruitful and that policy impact on growth will result into non-Pareto equilibrium position in the presence of weak institutions. Keefer and Knack (1995) using rule of law, repudiation of contracts by government, quality of bureaucracy, and insecurity of property rights among others, confirmed that institutions that protect property rights are crucial to economic growth.

Aisen and Veiga, (2013) investigating the influence of political stability on growth using data collected from a sample of 169 countries (1960 -2004). The panel dynamic model result reveals unstable polity has a declining effect on growth, not only through falling rate of productivity but also through a mild declining rate of physical and human capital accumulation. Acemoglu et al.(2005b) evaluate the importance of property rights and contracting institutions on growth using instrumental variables approach, the result suggest that countries which exert greater constraints on politicians and elites and more protection against expropriation by these powerful groups have substantially higher income per capita and greater investment rates, while when controlling for property rights the role of contracting institutions on the level of income per capita turns insignificant. Barro (2013), also investigates the relationship between inflation and economic growth using system equations, the result of the regression result indicates favourable public policies that ensure maintenance of rule of law and property rights, fewer distortions of private market, less unproductive government spending, and greater public investment in high -return areas- have a positive significant long run impact on growth while price instability has a declining impact on the growth rate of real per capita GDP by $0.4 \%-0.6 \%$.

Providing an empirical answer on reason behind sluggish growth experienced in sub- Saharan Africa using System-IV generalized method of moments approach to analyse panel data across 100 countries, Mahmud (2009) result reveals a direct correlation between economic growth and trade openness, temperate climate, human capital and institutions and an inverse relationship with initial income, price level, size of government and exchange rate over-valuation. Flachaire (2014) examines the role of institutions on growth experience of the growth process of developing and developed economies over the period 1970-2000. The fixed effect model indicate that political institutions are germane in the determination of the pattern of growth regime of an economy while economic institutions influence positively the growth rate, implying political institutions set the stage and provide an enabling environment in which economic policies can be effectively implemented.

Investigating the effect of environmental quality on growth, the result of panel Cointegration technique on a panel of 12 Middle East and North African (MENA) countries for the period 1981-2005 by Arouri et al., (2012) conclude that a quadratic relationship exists between real GDP and $\mathrm{CO}_{2}$ emissions in the region. In the same vein, Acemoglu, (2005a) conclude that 
environment determine the types of technology available to a society specifically in the agricultural sector and prevalence of diseases which in turns determine productivity and rate of poverty. Providing further empirical evidence in support of Acemoglu, (2005a), Bloom and Sachs (1998) revealed that the prevalence of malaria in sub-Saharan Africa, accounted for more than 1.3 percent (per annum) decline in the rate of growth of sub-Saharan African economies.

In summary, it can be argued that there has been a consensus among researchers that though traditional growth variables are required in the path to achieve sustainable economic growth, the complementary roles of policies remained fundamental. The proper mix of these policies variables required for factors efficiency depend on institutions. Therefore, institutional structures are key for desired macroeconomic outcomes.

\section{Methodology}

\subsection{Sources of Data and Variable Measurement}

Secondary data for fifty out of fifty- three African countries were collected and analysed for this study. The data were collected from two different sources. Data on real GDP, gross fixed capital formation, population growth, labour force, financial deepening, exchange rate, government expenditure, and $\mathrm{CO}_{2}$ were sourced from World Bank's 2015 world development indicators, while governance indicators, such as rule of law, political stability and government effectiveness were collected from World Governance Indicators. Economic growth was captured by real GDP per capita $\left(\mathrm{Y}_{\mathrm{t}}\right)$, real gross fixed capital formation was proxied by physical capital (Sk), while total number of labour force was used to measure the impact of human capital (Sh) on growth (see Bassanini, 2001; Raheem \& Yusuf, 2015). Government expenditure as percentage of GDP was employed to measure government size (Govz), while average official rate of exchange was used as proxy for rate of exchange (Exr) (Umoru, 2013; Chwukuma, 2013; Rodrik, 2009; Adebiyi 2004. Financial deepening (FDEP) as monetary variable is measured as ratio of M2/GDP

A measure of policy reform is globalisation (Glob) proxied by the total sum of export and import divided by total GDP. Proxies for institutional quality are: political stability (Polstb), government effectiveness (Dacc) and rule of law (Rl) (Owen, 2009; Kaufman, Kraay, and Mastruzzi, 2009; Flachaire, 2014). The data set collected for the series cover a period of 24 years (1990-2014).

\subsection{Model Specification}

Following extant literature, the following model was specified in line with work of Bassanini et al., 2001)

$\mathrm{GDP}_{\mathrm{t}}=\beta_{0}+\beta_{1} \mathrm{Sk}_{\mathrm{it}}+\beta_{2} \mathrm{Sh}_{\text {it }}+\beta_{3} \mathrm{Exr}_{\text {it }}+\beta_{4} \mathrm{Govz}_{\mathrm{it}}+\beta_{5} \mathrm{Fdep}_{\mathrm{it}+} \beta_{6} \mathrm{RL}_{\mathrm{it}}+\beta_{7} \mathrm{DACC}_{\mathrm{it}} \beta_{8} \mathrm{Postb}_{\mathrm{it}+}$ $\beta_{9} \mathrm{Co}_{2 \mathrm{it}}+\beta_{10} \mathrm{Govz}_{\text {it }}^{2}+\beta_{11} \mathrm{R}_{1 \mathrm{t}}^{2}+\beta_{12} \mathrm{Co}_{2 \mathrm{it}}^{2}+\mu_{\mathrm{t}}$

Where the series remained as earlier defined above while $\mu_{\mathrm{t}}$ represent white noise disturbance term at time $t, \beta_{0}$ is the intercept while $\beta_{1 \ldots \ldots . .12}$ are the coefficients to be estimated. 


\section{Nl Macrothink}

\subsection{Estimation Procedure}

The estimation of equation (3.1) commences with examination of the stability properties of the series in order to determine the stochastic properties of the variables. Four pooled unit root tests were conducted (PP-Fisher, Lm, Pesaran,\& Shin, Levin, ADF-Fisher and Levin Lu $\& \mathrm{Chu}$ ) using the equation (3.2).

$$
\Delta y_{i, t}=b_{i}+\rho Y_{i, t_{-}}+\sum_{k=1}^{\rho} \phi_{k} \Delta Y_{i, t-k}+\alpha_{i} t+\theta_{t}+\varepsilon_{i t}
$$

Where $b_{i}, \theta_{t}, \varepsilon_{i t}, \Delta, \rho_{i} y_{i}$ capture fixed effects for country $i$, specific time trend,

Gaussian white noise disturbance term for country $i$ at time $t$, difference term, lag order that is allow to vary across individuals, and the variables of interest respectively. The testing procedure follows a reference to the student $\mathrm{t}-$ ratio with respect to $\alpha$

The examination of the stationarity of the series followed the Johansen Fisher panel cointegration test to determine the existence of a long run relationship among the variables and a possible adjustment to equilibrium using the unrestricted vector error correction model (VECM) as follows:

$$
\begin{aligned}
& \Delta\left(G D P_{t}\right)_{t}=a_{0}+\sum_{i=1}^{j_{1}} a_{1 i} \Delta s_{k t-i}+\sum_{i=1}^{k_{1}} a_{21 i} \Delta s_{h t-i}+\sum_{i=1}^{l_{1}} a_{31 i} \Delta \operatorname{ext}_{t-i}+\sum_{i=1}^{m_{1}} a_{4 i} \Delta G o v z_{-i}+\sum_{i=1}^{o_{1}} a_{5 i} \Delta F d e p_{-i}+\sum_{i=1}^{p_{1}} a_{61 i} \Delta D a c c_{-i}+ \\
& \sum_{i=1}^{q_{1}} a_{71 i} \Delta \operatorname{Post}_{-i}+\sum_{i=1}^{q_{1}} a_{71 i} \Delta R l_{t-i}+\sum_{i=1}^{r_{1}} a_{8 i} \Delta c o_{2 t-i} \sum_{i=1}^{s_{1}} a_{9 i} \Delta G o v z_{t-i}^{2}+\sum_{i=1}^{t_{1}} a_{10 i} \Delta R l_{t-i}^{2}+\sum_{i=1}^{u_{1}} a_{11 t} \Delta c o_{2}^{2}{ }_{t-i}++b_{12} G D P_{t-1} t-i \\
& +b_{2} s_{h i j}(t)+b_{3} s_{h i j}(t)+b_{4} \operatorname{ex}_{i j}(t)+b_{5} \operatorname{Gov}_{i j}(t)+b_{6} F d e p_{j j}(t)+b_{7} \operatorname{dac}_{i j}(t)+b_{8} \operatorname{post} b_{i j}(t) \\
& \left.+b_{13} R l(t)+b_{14} C o_{2 i j}(t)+b_{15} g o v s z_{i j}^{2}(t)+b_{16} r l_{i j}^{2}(t)+b_{17} c o_{2}^{2}(t)++b_{218} e c m_{-1}+\mu_{t}\right)
\end{aligned}
$$

where the $\mathrm{i}=1, \ldots 11$ stands for the short-run dynamic coefficients, and parameters $: \mathrm{i}=$ $1, \ldots 18$ are the long-run multipliers. $\mathrm{a}_{\mathrm{o}}$ is the constant term. $i$ to $y$ are optimal lag of the respective variables and $\mathrm{b}_{1}$ to $b_{20}$ are the long run estimates of the variables including the error correction term.

\section{Result and Discussions}

\subsection{Pre-Estimation Tests}

Table 4.1 and Table 4.2 show the unit root and cointegration tests for the variables. First, all variables were initially transformed into natural log except for variables in rates. The results in Panel A, show that POPG, GEXP,GLOB, and RL tend to be stationary at level while $\mathrm{Y}_{\mathrm{t}}, \mathrm{SH}$, SK, EXR, FDEP, INF, DACC, POSTB, and $\mathrm{CO}_{2}$ are stationary at first difference going by the ADF-fisher, PP-Fisher, and Lm, Pesaran, and Shin results. The results of Levin, Lin \& Chu test in Panel B suggest that all the variables are stationary at first difference with the exemption of INF which is stationary at levels. A combination of the results in both panels A and B suggest that the variables employed are integrated of order (1). 
The result of Johansen-Fisher Panel Cointegration test at lag 1 is shown on Table 4.2. The trace statistics indicates the existence of at least four cointegrating equations while the maximal eigenvalues indicates the existence of at up to eight cointegrating vectors implying that the hypothesis of no cointegration is rejected at $1 \%$ level of significance for both maximal Eigenvalue $\left(\lambda_{\max }\right)$ and trace test statistics $\left({ }^{\lambda_{\text {trace }}}\right)$.Thus, there exist a long run relationship between GDP per capita $\left(\mathrm{Y}_{\mathrm{t}}\right)$ and all the right hand side variables used in the study.

Table 4.1 . Panel A: Panel Unit Root Test Results

\begin{tabular}{|c|c|c|c|c|c|c|}
\hline \multirow[b]{2}{*}{ Variables } & \multicolumn{2}{|c|}{ ADF-Fisher } & \multicolumn{2}{|c|}{ PP-Fisher } & \multicolumn{2}{|c|}{$\begin{array}{l}\text { Im, Pesaran \&Shin W- } \\
\text { Stat }\end{array}$} \\
\hline & $\begin{array}{l}\text { No } \\
\text { Trend }\end{array}$ & $\begin{array}{l}\text { Trend \& } \\
\text { Intercept }\end{array}$ & $\begin{array}{l}\text { No } \\
\text { Trend }\end{array}$ & $\begin{array}{l}\text { Trend \& } \\
\text { Intercept }\end{array}$ & No Trend & $\begin{array}{l}\text { Trend \& } \\
\text { Intercept }\end{array}$ \\
\hline$Y_{t}$ & 66.9297 & $170.189^{*}$ & 61.9656 & 104.892 & 4.7714 & $-2.6192^{*}$ \\
\hline $\mathrm{SH}$ & 116.332 & 44.3462 & $237.545^{*}$ & 42.4829 & $-2.4935^{*}$ & 9.1252 \\
\hline SK & 47.1646 & 114.395 & 34.3642 & 102.084 & 7.01100 & $-1.97201^{* *}$ \\
\hline POPG & $229.33^{*}$ & $184.334^{*}$ & $157.443^{*}$ & 124.444 & $-6.6390^{*}$ & -3.1950 \\
\hline GEXP & 63.7816 & $164.150^{*}$ & 77.1807 & $127.265^{*}$ & 4.8134 & $-2.5456^{*}$ \\
\hline GLOB & $135.444^{*}$ & $141.180^{*}$ & $150.261^{*}$ & $181.140^{*}$ & $-2.1631^{*}$ & -2.4476 \\
\hline EXR & 102.551 & 111.122 & 102.930 & $126.297^{*}$ & 102.930 & -0.6708 \\
\hline FDEP & $129.460^{*}$ & 177.142 & $120.921^{*}$ & 136.596 & -0.2043 & -3.8038 \\
\hline INF & 528.422 & $438.860^{*}$ & $534.302^{*}$ & $533.781^{*}$ & $-16.7886^{*}$ & $-16.7886^{*}$ \\
\hline RL & 111.971 & $209.856^{*}$ & 108.262 & $234.895^{*}$ & 0.00537 & $-5.3428^{*}$ \\
\hline $\mathrm{DACC}$ & 61.0336 & 67.3546 & $122.813^{*}$ & $217.709^{*}$ & 2.5931 & 1.6187 \\
\hline POSTB & 60.1357 & 72.1244 & 101.810 & $196.917^{*}$ & 2.112 & 0.6376 \\
\hline $\mathrm{CO} 2$ & 103.485 & 88.7897 & 103.700 & $394.460^{*}$ & -0.0104 & -0.2115 \\
\hline$\Delta Y_{t}$ & $263.466^{*}$ & $165.490^{*}$ & $637.945^{*}$ & $1026.66^{*}$ & $-8.0780^{*}$ & $-4.0605^{*}$ \\
\hline$\Delta \mathrm{SH}$ & 42.0742 & 41.5207 & 57.7476 & 49.0164 & 5.3650 & 31.2584 \\
\hline$\Delta \mathrm{SK}$ & $770.592^{*}$ & $637.245^{*}$ & $814.041^{*}$ & $1307.92^{*}$ & $-27.9942^{*}$ & $-24.9252^{*}$ \\
\hline$\triangle P O P G$ & $164.096^{*}$ & 634.998 & $268.939^{*}$ & $425.124^{*}$ & $-4.8219^{*}$ & $-19.8538^{*}$ \\
\hline$\triangle G E X P$ & $212.217^{*}$ & $133.825^{*}$ & $894.325^{*}$ & $1423.33^{*}$ & $-6.8160^{*}$ & $-3.1716^{*}$ \\
\hline$\triangle \mathrm{GLOB}$ & $288.385^{*}$ & $230.765^{*}$ & $1254.18^{*}$ & $1947.07^{*}$ & $-10.1097^{*}$ & $-7.8031^{*}$ \\
\hline$\triangle E X R$ & $593.114^{*}$ & 471.318 & $564.173^{*}$ & 478.100 & $-21.7394^{*}$ & -18.5718 \\
\hline$\triangle F D E P$ & $830.822^{*}$ & $652.908^{*}$ & $1202.86^{*}$ & $2145.05^{*}$ & $-29.2076^{*}$ & $-25.6055^{*}$ \\
\hline$\triangle I N F$ & $1118.10^{*}$ & $1006.87^{*}$ & $3340.38^{*}$ & $7053.43^{*}$ & $-39.0234^{*}$ & $-33.0931^{*}$ \\
\hline$\Delta R L$ & $211.190^{*}$ & $1029.00^{*}$ & $1859.96^{*}$ & $2574.96^{*}$ & $-7.2343^{*}$ & $-38.1966^{*}$ \\
\hline$\triangle D A C C$ & $206.293^{*}$ & $3962.05^{*}$ & $1651.92^{*}$ & $3962.05^{*}$ & $-7.0598^{*}$ & $-4.0042^{*}$ \\
\hline$\triangle P O S T B$ & $201.919^{*}$ & $130.228^{*}$ & $1536.42^{*}$ & $1856.34^{*}$ & $-6.7916^{*}$ & $-3.2737^{*}$ \\
\hline
\end{tabular}

Source: Author's computations using EViews 8.0. 


\section{Macrothink}

Table 4.2. Panel Cointegration Test Results

\begin{tabular}{ccllll}
\hline \multicolumn{1}{c}{ Hypothesized } & $\begin{array}{l}\text { Fisher Stat } \\
\left(\lambda_{\text {trace }}\right)\end{array}$ & Prob & $\begin{array}{l}\text { Fisher } \\
\text { Stat. }\left(\lambda_{\max }\right.\end{array}$ & Prob. \\
Null & Alternative & & & & \\
\hline None & & 67.93 & 0.9911 & 67.93 & 0.9911 \\
$\mathrm{r}=0$ & $\mathrm{r} \geq 1$ & 62.38 & 0.9981 & $136.1^{*}$ & 0.0066 \\
$\mathrm{r}=1$ & $\mathrm{r} \geq 2$ & 37.43 & 1.0000 & $442.7^{*}$ & 0.0000 \\
$\mathrm{r}=2$ & $\mathrm{r} \geq 3$ & 1.386 & 1.0000 & $885.6^{*}$ & 0.0000 \\
$\mathrm{r}=3$ & $\mathrm{r} \geq 4$ & 884.2 & $0.0000^{*}$ & $902.6^{*}$ & 0.0000 \\
$\mathrm{r}=4$ & $\mathrm{r} \geq 5$ & 1638. & $0.0000^{*}$ & $1091^{*}$ & 0.0000 \\
$\mathrm{r}=5$ & $\mathrm{r} \geq 6$ & 862.5 & $0.0000^{*}$ & $564.4^{*}$ & 0.0000 \\
$\mathrm{r}=6$ & $\mathrm{r} \geq 7$ & 459.5 & $0.0000^{*}$ & $369.4^{*}$ & 0.0000 \\
$\mathrm{r}=7$ & $\mathrm{r} \geq 8$ & 266.6 & $0.0000^{*}$ & $266.6^{*}$ & 0.0000 \\
\hline
\end{tabular}

$\mathrm{r}$ indicates the number of cointegrating vectors. ${ }^{*}$ indicates rejection of the null hypothesis at $5 \%$ level of significance.

Source: Authors' Computation Using Eviews 8.0.

\subsection{Analysis and Discussion of Regression Results}

Table 4.3 panel A presents a panel Cointegration regression both in the short run and long run. The coefficients of stock of capital (SK) exhibit a positive significant impact on economic growth across all models. The results of this study are consistent with the findings of Krugman, 1994; Bassanini, 2002; Young, 2004; and Kallon, 2013). It confirms the endogenous growth theory which posits that investment in R\&D results in technology accumulation which in turn increases output (see, Romer, 1986) or at worst, growth remains at a steady state ( see, Barro,1990; Rebelo, 1991). The long run estimates indicate an insignificant detrimental impact of human capital on growth,

Table 4.3 panel A shows that the short run exhibits a positive and significant impact of physical capital on economic growth. On an average, it can be concluded that qualitative human capital is germane to the desired economic outcomes in Africa, in line with earlier findings by Bassanini et al. (2002), Temple (2001), Jens et al. (2011), and Gennaioli (2014). The negative and insignificant coefficient of human capital portrays the inconsistencies and unsustainable patterns of policies aimed at improving the quality of human capital (particularly educational system) by most African countries. The impact of population size is insignificant in both periods indicating that Africa's population size has insignificant impacts on economic growth. Government expenditure is positive but insignificant implying that that big government size is required for good economic performance in Africa against earlier empirical evidence by (Kui-Wai Li et al., 2011 and Ouechtati et al., 2013). The insignificance of the coefficients may be due to weak institutions of individual countries as observe red by (ICRG, 2015).

The impact of globalisation on growth is positive and significant both in the short run and in long run. This is in conformity with the work of Aghion (2006), Kui-Wai Li et al. (2011), and 
Ouechtati et al. (2013). Contrarily, an Aka (2004) result presents a negative impact of growth, while Utpal's (2011) submits that the effect of globalisation on economic growth is unclear due to structural rigidities.

On an average, exchange rate and rate of inflation have negative impacts on growth, consistent with the empirical findings of Babatunde (2009) in a panel study of Sub-Saharan African countries; Garcia et al., (2013) in a cross countries study of OECD and non-OECD countries, and Martins et al. (2014) in a country specific study. The negative impact is aggravated by the devaluation policy adopted by most African countries in the 1990's and early 2000's.

Financial deepening has a negative significant impact on growth of GDP per capita in the short run. This contradicts the work of O' Connell (2000) who found a positive impact of financial deepening on growth in Sub-Saharan Africa. In the long run, financial deepening tends to exert an insignificant positive impact on growth in line with O'Connell (2000) but contradicts the conclusions by Wong and Zhou (2011) and Barajas et al. (2013). The change in sign of the coefficient from negative in the short run to a positive in the long run suggests that policies aimed at increasing the breadth and reach of the financial system might not be instantaneous but lag in its effect.

In the long run estimates, the rule of law (RL) and democratic accountability (DACC) have negative and positive significant effects on economic growth respectively while in the short run it exerts positive significant impacts on growth. These findings are consistent with those of Sarwar et al. (2013), Flachaire (2014), Mbulawa, (2015), among others. The positive impact of the rule of law indicates that efficient and effective rule of law ensure enforcement of contracts and the protection of property rights, all of which are capable of ensuring equality of access necessary for inclusive growth. The negative effect of rule of law on growth in the long run indicates that the implementation of rules in Africa has always been on unsustainable basis.

Political stability has a positive and insignificant impact in the short run and a significant and positive effect in the long run on economic growth, indicating that all things being equal, a stable polity would result in policy effectiveness due to continuity. The short run effect of political stability (POSTB) reflects the rent seeking behaviour among most African necessitated by the need to garner support from their political gladiator.

In the long run and short run, environmental quality has a positive and significant impact on growth. Surprisingly not, all African economies rely majorly on the economic activities in primary sector for survival. Majority of these countries are either oil rich economies with larger percentage of their national income coming from crude export or agricultural produce exporting countries, therefore, environment becomes a positive function of income.

The estimate of the square of government expenditure (GEXP) and rule of law (RL) were used to test for the possible existence of a turning point in the effects of each of the variables on economic growth. Going by the long run intercept term that is negative and significant, the coefficient of GEXP is positive, while the coefficient of $\mathrm{GEXP}^{2}$ is negative and almost zero, 


\section{Macrothink

suggesting the possible existence of a turning point for government size in line with Narayan and Narayan (2010). However, the coefficients of GEXP and GEXP ${ }^{2}$ are insignificant indicating the possibility of a weak turning point between GEXP and GDP per capita. In Narayan and Narayan (2010) model $\mathrm{CO}_{2}$ is negative and significant, while the square of $\mathrm{CO}_{2}$ is positive and significant and almost zero, indicating of a U-shaped relationship between GDP per capita and environmental degradation.

In the short run, the coefficient GEXP is positive, government size elasticity is also positive and the square of the GEXP is almost zero, indicating that the bigger the size of government, the higher the level of income up to a certain point beyond which, the growth rate tends to decline. This is evidenced in the work (Chang, 2011). This is however temporal because in the long run, property right will continue to have a long-lasting positive impact on GDP per capita, indicating the absence of turning point for rule of law in the long run.

Table 4.3. Panel A: long run estimates

\begin{tabular}{|c|c|c|c|}
\hline \multicolumn{4}{|c|}{ Dependent Variable $\Delta Y t$} \\
\hline Variables & Coefficient & Std. Error & t-Statistic \\
\hline $\mathrm{C}$ & $-0.226690^{*}$ & 0.076565 & -2.960735 \\
\hline $\mathrm{YT}_{\mathrm{t}-1}$ & $0.982298^{*}$ & 0.003861 & 254.3955 \\
\hline SK ${ }^{\mathrm{t}-1}$ & $0.018596^{*}$ & 0.003327 & 5.589125 \\
\hline $\mathrm{SH}_{\mathrm{t}-1}$ & -0.001116 & 0.001707 & -0.653497 \\
\hline POPG & 0.000718 & 0.000629 & 1.140992 \\
\hline GEXP & 0.004408 & 0.005329 & 0.827219 \\
\hline GLOB & $0.055304^{*}$ & 0.007053 & 7.841514 \\
\hline $\mathrm{EXR}_{t-1}$ & -2.4406 & $1.80 \mathrm{E}-06$ & -1.359345 \\
\hline INF $t-1$ & -4.8307 & $3.42 \mathrm{E}-06$ & -0.141176 \\
\hline FDEP & 6.6505 & 0.000129 & 0.514832 \\
\hline RL & $-0.037995^{* *}$ & 0.013259 & -2.865683 \\
\hline DACC & $0.020535^{* * * *}$ & 0.011230 & 1.828622 \\
\hline POSTB & $0.009554^{* * *}$ & 0.004721 & 2.023799 \\
\hline $\mathrm{CO} 2 \mathrm{t}-2$ & $-0.012296^{*}$ & 0.003637 & -3.380801 \\
\hline $\mathrm{RL}^{2}$ & $-0.010145^{* * *}$ & 0.005998 & -1.691456 \\
\hline$\left(\mathrm{GEXP}_{\mathrm{t}-1}\right)^{2}$ & $-0.000179^{* * *}$ & 0.000124 & -1.444218 \\
\hline $\mathrm{CO}^{2}$ & $0.000455^{* * * *}$ & 0.000266 & 1.707402 \\
\hline $\mathrm{C}$ & $-0.226690^{*}$ & 0.076565 & -2.960735 \\
\hline \multicolumn{4}{|l|}{ Diagnostics } \\
\hline $\mathrm{R}^{2}$ & \multicolumn{2}{|c|}{0.998} & \\
\hline Adj. $R^{2}$ & \multicolumn{2}{|c|}{0.992} & \\
\hline S.E. & \multicolumn{2}{|c|}{0.092828} & \\
\hline F. Stat. & \multicolumn{2}{|c|}{$10130.50(0.0000)$} & \\
\hline D.W. & \multicolumn{2}{|c|}{1.84} & \\
\hline
\end{tabular}

Note. ${ }^{*}{ }^{* *}$ and ${ }^{* * *}$ represent $1 \%, 5 \%$ and $10 \%$ level of significant respectively.

Source: Author's computation Using EViews 8.0 


\section{Macrothink}

Table 4.3. Panel B: Short Run Estimates

Dependent Variable $\Delta \mathrm{Yt}$

\begin{tabular}{|c|c|c|c|}
\hline Variables & Coefficient & Std. Error & t-Statistic \\
\hline C & 0.002688 & 0.005465 & 0.491883 \\
\hline$\Delta Y T_{t-1}$ & $0.163496^{*}$ & 0.029096 & 5.619099 \\
\hline$\Delta S K)$ & $0.048607^{*}$ & 0.008112 & 5.991686 \\
\hline$\triangle \mathrm{SH}$ & $0.404791^{* * *}$ & 0.177434 & 2.281364 \\
\hline$\triangle P O P G$ & 0.001157 & 0.005017 & 0.230571 \\
\hline$\triangle G E X P_{t-1}$ & 0.001096 & 0.005132 & 0.213507 \\
\hline$\triangle \mathrm{GLOB}_{\mathrm{t}-1}$ & $0.056364^{*}$ & 0.015395 & 3.661323 \\
\hline$\triangle F D E P_{t-1}$ & $-0.003058^{*}$ & 0.000344 & -8.880329 \\
\hline$\Delta \mathrm{E} X \mathrm{R}_{\mathrm{t}-1}$ & -9.542474 & 7.08E-06 & -1.347173 \\
\hline$\Delta I N F F_{t-1}$ & 1.046117 & $2.43 E-06$ & 0.429705 \\
\hline$\Delta R L$ & $0.047452^{* * *}$ & 0.024969 & 1.900405 \\
\hline$\triangle \mathrm{DACC}$ & 0.002326 & 0.024496 & 0.094952 \\
\hline$\triangle P O S T B_{t-1}$ & 0.014262 & 0.011540 & 1.235880 \\
\hline$\triangle \mathrm{CO}_{2}$ & $0.046843^{*}$ & 0.011746 & 3.987946 \\
\hline$\triangle G E X P^{2}$ & -0.002242 & 0.001599 & -1.401720 \\
\hline$\Delta \mathrm{RL}^{2}$ & -0.017452 & 0.067259 & -0.259475 \\
\hline$\triangle \mathrm{CO}^{2}$ & -0.005830 & 0.004184 & -1.393631 \\
\hline $\mathrm{ECM}_{\mathrm{t}-1}$ & $-0.015219^{*}$ & 0.003558 & -4.277871 \\
\hline \multicolumn{4}{|l|}{ Diagnosties } \\
\hline $\mathbf{R}^{2}$ & 0.17 & & \\
\hline Adj. $R^{2}$ & 0.15 & & \\
\hline S.E. & 1.899579 & & \\
\hline F. Statistics & 13.29275 & & \\
\hline Prob. F-Stat. & 0.000000 & & \\
\hline D.W & 1.960230 & & \\
\hline
\end{tabular}

Note. $^{*},{ }^{* *}$ and ${ }^{* * *}$ represent $1 \%, 5 \%$ and $10 \%$ level of significant respectively.

Source: Author's computation using EViews 8.0

\subsection{Causality Test Results}

Table 4.4 provides the vector error correction model Granger non-causality tests for macroeconomic policy, institutions and traditional growth variables. The short run causality test indicates that causality flows from all the explanatory variables mostly at $1 \%$ significance level with the exemption of human capital, inflation rate, rule of law and government effectiveness (proxies by DACC) to GDP per capita. The overall causality test (i.e. the strong exogeneity) results suggest that the null hypothesis that macroeconomic policy, institutions and other traditional growth variables with the exemption of (SH) and (INF), do not Granger-cause economic growth is rejected at varying degrees of significance.

The feedback responses from the dependent variable to all the explanatory variables in the long run are presented in Panel B of Table 5. The results of the weak exogeneity (long run causality) shows that economic growth Granger-causes exchange rate (EXR), rule of law (Rl), Political Stability (POLSTB) and $\mathrm{CO}_{2}$ at $1 \%, 10 \%$, and $1 \%$ significance levels respectively, thus confirming a bi-directional relationship between growth in income, exchange rate, rule of law and $\mathrm{CO}_{2}$ in the long run. 
Table 4.4 here

Table 4.4. Granger Non-causality Test Results

\begin{tabular}{|c|c|c|c|}
\hline Hypothesis & Long-run & Short Run & Strong Exogeneity \\
\hline Ho: $\Delta \mathrm{SK} \rightarrow \Delta \mathrm{Yt}$ & $\beta Y t \phi_{t-1}=\mathbf{O}$ & $\Delta \mathrm{SK}_{\mathrm{t}-1}=\mathrm{O}$ & $\Delta \mathrm{SK}_{\mathrm{t}-\mathrm{i}}=\beta Y t \phi_{t-1}=\mathbf{O}$ \\
\hline$\chi^{2}$ & $3.128397^{* * *}$ & $9.481087^{*}$ & $11.93856^{*}$ \\
\hline Ho: $\triangle \mathrm{SH} \rightarrow \Delta \mathrm{Yt}$ & & $\Delta \mathrm{SH}_{\mathrm{t}-\mathrm{i}}=\mathrm{O}$ & $\Delta \mathbf{S H}_{\mathrm{t}-\mathrm{i}}=\beta Y t \phi_{t-1}=\mathbf{0}$ \\
\hline$\chi^{2}$ & & 0.971998 & 3.131639 \\
\hline Ho: $\triangle \mathrm{POPG} \rightarrow \Delta \mathrm{Yt}$ & & $\Delta \mathrm{POPG}_{\mathrm{t}-\mathrm{i}}=\mathrm{O}$ & $\Delta \mathrm{POPG}_{\mathrm{t}-\mathrm{i}}=\beta Y t \phi_{t-1}=\mathbf{O}$ \\
\hline$\chi^{2}$ & & $3.314923^{* * *}$ & $6.565149^{* *}$ \\
\hline Ho: $\triangle \mathrm{GEXP} \rightarrow \Delta \mathrm{Yt}$ & & $\Delta \mathrm{GEXP} P_{\mathrm{t}-\mathrm{i}}=\mathrm{O}$ & $\Delta \mathrm{GEXP}_{\mathrm{t}-\mathrm{i}}=\beta Y t \phi_{t-1}=\mathbf{O}$ \\
\hline$\chi^{2}$ & & $35.26370^{*}$ & $39.00876^{*}$ \\
\hline Ho: $\triangle \mathrm{GLOB} \rightarrow \Delta \mathrm{Yt}$ & & $\Delta \mathrm{GLOB}_{\mathrm{t}-\mathrm{i}}=\mathrm{O}$ & $\Delta \mathrm{GLOB}_{\mathrm{t}-\mathrm{i}}=\beta Y t \phi_{t-1}=\mathbf{0}$ \\
\hline$\chi^{2}$ & & $13.64573^{*}$ & $14.85476^{*}$ \\
\hline Ho: $\triangle \mathrm{EXR} \rightarrow \Delta \mathrm{Yt}$ & & $\Delta \mathrm{EXR}_{\mathrm{t}-\mathrm{i}}=\mathrm{O}$ & $\Delta \mathrm{EXR}_{\mathrm{t}-\mathrm{i}}=\beta Y t \phi_{t-1}=\mathbf{O}$ \\
\hline$\chi^{2}$ & & $99.44771^{*}$ & $99.67672^{*}$ \\
\hline Ho: $\triangle \mathrm{INF} \rightarrow \Delta \mathrm{Yt}$ & & $\Delta \mathrm{INF}_{\mathrm{t}-\mathrm{i}}=\mathrm{O}$ & $\Delta \mathbf{I N F}_{\mathrm{t}-\mathrm{i}}=\beta Y t \phi_{t-1}=\mathbf{O}$ \\
\hline$\chi^{2}$ & & 0.165105 & 3.312033 \\
\hline Ho: $\triangle F D E P \longrightarrow \triangle Y \mathrm{Yt}$ & & $\Delta F D E P_{t-i}=0$ & $\Delta \mathrm{FDE} \mathbf{P}_{\mathrm{t}-\mathrm{i}}=\beta Y t \phi_{t-1}=\mathbf{O}$ \\
\hline$\chi^{2}$ & & $17.06681^{*}$ & $20.50754^{*}$ \\
\hline Ho: $\Delta \mathrm{RL} \rightarrow \Delta \mathrm{Yt}$ & & $\Delta R L_{t-i}=0$ & $\Delta \mathbf{R L}_{\mathbf{t}-\mathrm{i}}=\beta Y t \phi_{t-1}=\mathbf{O}$ \\
\hline$\chi^{2}$ & & 1.278844 & $4.675566^{* * *}$ \\
\hline Ho: $\triangle \mathrm{DACC} \rightarrow \triangle \mathrm{Yt}$ & & $\triangle \mathrm{DACC} \mathrm{t}_{\mathrm{t}-\mathrm{i}}=\mathrm{O}$ & $\Delta \mathrm{DACC} C_{\mathrm{t}-\mathrm{i}}=\beta Y t \phi_{t-1}=\mathbf{O}$ \\
\hline$\chi^{2}$ & & 0.545927 & $3.875467^{* * *}$ \\
\hline Ho: $\triangle \mathrm{POSTB} \rightarrow \Delta \mathrm{Yt}$ & & $\Delta$ POSTB $_{t-i}=0$ & $\Delta \operatorname{POSTB}_{\mathrm{t}-\mathrm{i}}=\beta Y t \phi_{t-1}=\mathrm{O}$ \\
\hline$\chi^{2}$ & & $3.786209^{* * *}$ & $6.701164^{* *}$ \\
\hline Ho: $\triangle \mathrm{CO} 2 \rightarrow \Delta \mathrm{Yt}$ & & $\Delta \mathrm{CO} 2_{\mathrm{t}-\mathrm{i}}=\mathrm{O}$ & $\Delta \mathrm{CO} 2_{\mathrm{t}-\mathrm{i}}=\beta Y t \phi_{t-1}=\mathbf{O}$ \\
\hline$x^{2}$ & & $635.9485^{*}$ & $635.9669^{*}$ \\
\hline
\end{tabular}

Source: Author's computation, using Eviews 8.0

Note. ${ }^{*},{ }^{* *}$ and ${ }^{* * *}$ represent $1 \%, 5 \%$ and $10 \%$ level of significance respectively. Numbers in parenthesis indicate the degree of freedom for the chi-square statistics.

Source: Author's computation, using EViews 8.0

The result of the short run non-causality tends to confirm the existence of bidirectional causality between all the explanatory variables and GDP per capita, with the exemption of openness, inflation, rule of law and democratic accountability which tend to have a unidirectional causality running from GDP per capita. The strong exogeneity test provides evidence of bidirectional causality between economic growth and other variables in the system.

The existence of bidirectional relationship between institutional variables and growth in the long run is underscore by the fact that building strong institutions is costly and requires greater resources for its effective implementation, which could only be provided by a rich economy (see Lipset, 1960; Alvarez et al., 2000). Viewed from another perspective, institutions determine the societal super structure upon which production functions were built, in line with the Marx's theory of dialectic materialism. For Marx, an advanced productive force was the pillar of change in social production relations and society superstructure, which includes institutions. 
Table 4. Granger Non-causality Test Results Panel B: Causality from $Y_{t}$ to other variables

\begin{tabular}{|c|c|c|c|}
\hline Hypothesis & $\begin{array}{c}\text { Weak } \\
\text { Exogeneity }\end{array}$ & $\begin{array}{l}\text { Short Run } \\
\text { Non-Causality }\end{array}$ & Strong Exogeneity \\
\hline Ho: $\triangle Y Y t \longrightarrow \triangle S K$ & $\beta S K \quad \phi_{t-1}=0$ & $\Delta Y t_{t-1}=O$ & $\beta S K \quad \phi_{t-1}=\Delta \mathbf{Y t}_{\mathbf{t}-\mathbf{i}}=\mathbf{O}$ \\
\hline$x^{2}$ & 0.181574 & $27.27569(1)^{*}$ & $27.67809(2)^{*}$ \\
\hline Ho: $\triangle Y_{t} \longrightarrow \Delta S H$ & $\beta S H \quad \phi_{t-1}=0$ & & $\beta S H \quad \phi_{t-1}=\Delta \mathbf{Y t}_{\mathbf{t}-\mathbf{i}}=\mathbf{O}$ \\
\hline$x^{2}$ & 0.344572 & & $27.71854(2)^{*}$ \\
\hline Ho: $\triangle Y \mathrm{Yt} \longrightarrow \triangle \mathrm{DPOPG}$ & $\beta P O P G \quad \phi_{t-1}=0$ & & $\beta P O P G \quad \phi_{t-1}=\Delta \mathbf{Y} \mathbf{t}_{\mathbf{t}-\mathbf{i}}=\mathbf{O}$ \\
\hline$x^{2}$ & 0.140095 & & $27.39543(2)^{*}$ \\
\hline Ho: $\triangle Y Y \longrightarrow \triangle G E X P$ & $\beta G E X P \quad \phi_{t-1}=0$ & & $\beta G E X P \quad \phi_{t-1}=\Delta \mathbf{Y} \mathbf{t}_{\mathbf{t}-\mathbf{i}}=\mathbf{O}$ \\
\hline$x^{2}$ & 1.715813 & & $29.01136(2)^{*}$ \\
\hline Ho: $\triangle \mathrm{Yt} \longrightarrow \triangle \mathrm{GLOB}$ & $\beta G L O B \quad \phi_{t-1}=0$ & & $\beta G L O B \quad \phi_{t-1}=\Delta \mathbf{Y t}_{\mathbf{t}-\mathbf{i}}=\mathbf{O}$ \\
\hline$x^{2}$ & 0.514730 & & $27.66013(2)^{*}$ \\
\hline Ho: $\triangle Y Y t \rightarrow \triangle E X R$ & $\beta E X R \quad \phi_{t-1}=0$ & & $\beta E X R \quad \phi_{t-1}=\Delta \mathbf{Y} \mathbf{t}_{\mathbf{t}-\mathbf{i}}=\mathbf{O}$ \\
\hline$x^{2}$ & $31.39504^{*}$ & & $57.00810(2)^{*}$ \\
\hline Ho: $\triangle$ Yt $\longrightarrow \triangle \mathrm{INF}$ & $\beta I N F \quad \phi_{t-1}=0$ & & $\beta I N F \quad \phi_{t-1}=\Delta \mathbf{Y t}_{\mathbf{t}-\mathbf{i}}=\mathbf{O}$ \\
\hline$x^{2}$ & 0.032182 & & $27.32605(2)^{*}$ \\
\hline Ho: $\triangle Y Y \longrightarrow \triangle F D E P$ & $\beta F D E P \quad \phi_{t-1}=0$ & & $\beta F D E P \quad \phi_{t-1}=\Delta \mathbf{Y t}_{\mathbf{t}-\mathbf{i}}=\mathbf{O}$ \\
\hline$x^{2}$ & 0.063607 & & $27.31219(2)^{*}$ \\
\hline 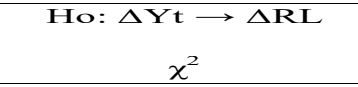 & $\begin{array}{l}\beta R L \quad \phi_{t-1}=0 \\
3.274323^{* * * *}\end{array}$ & & $\begin{array}{c}\beta R L \quad \phi_{t-1}=\Delta Y \mathbf{t}_{\mathbf{t}-\mathbf{i}}=O \\
31.011447(2)^{*}\end{array}$ \\
\hline Ho: $\triangle \mathrm{Yt} \longrightarrow \triangle \mathrm{DACC}$ & $\beta D A C C \quad \phi_{t-1}=0$ & & $\beta D A C C \quad \phi_{t-1}=\Delta \mathbf{Y t}_{\mathbf{t}-\mathbf{i}}=\mathbf{O}$ \\
\hline$x^{2}$ & 0.476872 & & $28.19028(2)^{*}$ \\
\hline HO: $\triangle Y \mathrm{Yt} \longrightarrow \triangle \mathrm{PPOSTB}$ & $\beta$ POSTB $\quad \phi_{t-1}=0$ & & $\beta$ POSTB $\quad \phi_{t-1}=\Delta \mathbf{Y t}_{\mathbf{t}-\mathbf{i}}=\mathbf{O}$ \\
\hline$x^{2}$ & 1.1311716 & & $27.62472(2)^{*}$ \\
\hline Ho: $\triangle Y_{t} \longrightarrow \triangle \mathrm{CO}^{2}$ & $\beta C O \quad 2 \phi_{t-1}=0$ & & $\beta C O \quad 2 \phi_{t-1}=\Delta \mathbf{Y} \mathbf{t}_{\mathbf{t}-\mathbf{i}}=\mathbf{O}$ \\
\hline$x^{2}$ & $27.27569^{*}$ & & $212.2622(2)^{*}$ \\
\hline
\end{tabular}

Source: Author's computation, using EViews 8.0

Note. ${ }^{*},{ }^{* *}$ and ${ }^{* * *}$ represent $1 \%, 5 \%$ and $10 \%$ level of significance respectively. Numbers in parenthesis indicate the degree of freedom for the chi-square statistics.

\section{Conclusion and Recommendation}

This study investigates the relationship between macroeconomic policies, institutions and economic growth in Africa from 1990-2014. To achieve this, the study adopted the panel cointegration framework to investigate the short and long run effects of the explanatory variables on GDP per capita while the existence of both long run and short run cointegration Causality tests were also carried out using Panel Vector Error Correction Model (VECM). The results showed a long run relationship between the explanatory variables and economic growth with a very slow rate of adjustment mechanism. In addition, monetary policy variables have negative impacts on economic growth. Another vital result obtained in the study is that rule of law has no turning point on its positive impact on growth in the long run while large government size will in the long run have a detrimental impact on economic growth in Africa. Finally, the study reveals bidirectional causality between all the explanatory variables and economic growth with the exception of labour and inflation rate that exhibited a unidirectional causality running from each of the variables to economic growth. The study recommends that for sustainable growth, Africa's educational system and other manpower development programmes need to be improved upon in order to maximize the advantage of 
large labour force as well as turning the high population growth rate in Africa into blessing rather than a curse. To guard against negative impact of monetary policy variables, African countries should strive towards changing the direction of trade from a mere export of primary product or semi-finished goods to tradable goods and reduce their import basket. Above all government should limit its activities to regulatory roles and provision of enabling environment for a private sector led economy.

\section{References}

Abranmovitz, M. (1956). Resources and Output Trends in the United States Since 1870. American Journal Review, 46, 5-23.

Acemoglu, D., \& Johnson, S. (2005b). Unbundling Institutions. Journal of Political Economy, 113(5), 949-995. https://doi.org/10.1086/432166

Acemoglu, D., Johnson, S., \& Robinson, J. A. (2005a). Institutions as a Fundamental Cause of Long-Run Growth. Handbook of Economic Growth (Volume IA. Edited by Philippe Aghion and Steven N. Durlauf, pp.387-472). https://doi.org/10.3386/w10481

Acemoglu, D., \& Robinson, J. (2012). Why Nations Fail?. New York Crown Publishers

Acemoglu D., Johnson, S. \& Robinson, J. (2000). The Colonial Origins of Comparative Development. American Economic Review, 91(5), 1369-1401. https://doi.org/10.1257/aer.91.5.1369

Adebiyi A. M., \& Babatope-Obasa, B. (2004). Institutional Framework, Interest Rate Policy and the Financing of the Nigerian Manufacturing Sub-Sector. Africa Development and Poverty Reduction: The Macro-Micro Linkage Forum Paper No 2004 Lord Charles Hotel, Somerset West, South Africa 13 - 15 October 2004

Aghion, P., Bacchetta, P., Ranciere, R., \& Rogoff, K. (2006). Exchange Rate Volatility and Productivity Growth: The Role of Financial Development. NBER Working Paper No. 12117. https://doi.org/10.3386/w12117

Aisen, A., \& Veiga, F. J. (2013). How Does Political Instability Affect Economic Growth?" European Journal of Political Economy, 29, 151-167. https://doi.org/10.1016/j.ejpoleco.2012.11.001

Alvarez M., Cheibub J.A., Limongi F., \& Przeworski A. (2000). Democracy and Development: Political Institutions and Material Well-Being in the World. 1950-1990, Cambridge; Cambridge University Press.

Arouri, M. E. H., Ben Y. A., M'henni, H., \& Rault, C. (2012), Energy Consumption, Economic Growth and CO2 Emissions in Middle East and North African Countries. Energy Policy, Elsevier, 45(C), 342-349. https://doi.org/10.1016/j.enpol.2012.02.042

Babatunde, A. (2009). Determinats of Export Performance in Sub-Sharan Africa. In Adenikinju A., Busari D. and Olofin S. (eds.), Applied Econometrics and Macroeconometric Modelling in Nigeria (pp. 327-347). Ibadan University Press. Ibadan. 


\section{Macrothink}

Journal of Asian Development

ISSN 2377-9594

2019, Vol. 5, No. 2

Balami D. H. (2006). Macroeconomic Theory and Practice (pp. 108-127). Salawe Prints, Maiduguri, Nigeria.

Barajas, A., Chami, R., \& Yousefi, S. R. (2013). The impact finance and Growth Nexus Reexamined: Do all Countries Benefited Equally? IMF Working Paper No. 13/130, Pp.1-33.

https://doi.org/10.5089/9781484372104.001

Barro R. J. (1990). Government Spending in a Simple Model of Endogenous Growth. Journal of Political Economy, 95(5), part 2, 103-125. https://doi.org/10.1086/261726

Barro R. J. (2013). Inflation and Economic Growth. Annals of Economics and Finance, Society for AEF, 14(1), 121-144, May.

Bassanini A., \& Scarpetta, S. (2002). Does Human Capital Matter for Growth in OECD Countries"? A Pooled Mean-group Approach. Economics Letters, 74, 399-405. https://doi.org/10.1016/S0165-1765(01)00569-9

Bassanini, A., \& Scarpetta, S. (2001). The Driving Force of Economic Growth: Evidence for the OECD Countries. OECD Economic Studies, 33, 2001/11. https://doi.org/10.1787/eco_studies-v2001-art10-en

Bloom, D. E., \& Sachs, J. D. (1998). Geography, Demography, and Economic Growth in Africa". Brookings Papers on Economic Activity, Vol.2, pp. 207-295. In Acemoglu D. Johnson S., and Robinson J. A. (2005), Institutions as a Fundamental Cause of Long-Run Growth." Handbook of Economic Growth, Volume IA. Edited by Philippe Aghion and Steven N. Durlauf, pp. 387-472. https://doi.org/10.2307/2534695

Chang, H.-J. (2011). Institution and Economic Development: Theory, Policy and History. Journal of Institutional Economics, $\quad 7(4), \quad 473-498$. https://doi.org/10.1017/S1744137410000378

Chukwuma, A., \& Aldo, C. (2013). Economic Diversification and Macroeconomic Policies: Re-Examining the Missing Link in Africa's Industrialization Strategies. A conference paper presented at UNU-WIDER's conference, held in Helsinki on 24-25 June 2013.

Denison E. F. (1967). Why Growth Rates Differ. Washington D. C., The Brookings Institution.

Dougherty, C., \& Dale, W. J. (1996). International Comparisons of the Sources of Economic Growth. American Economic Association Papers and Proceedings, 86, 25-29.

Easterly, W., \& Levine, R. (2001). What have we learned from decade of Empirical Research on Growth? Its not Factor Acummu;ation : Stylized fact and Growth models. World Bank Economic review, 15(2), 177-219.

Engen, E., \& Sklinner, J. (1992). Fiscal policy and Economic Growth. NBER Working PaperNo. 4223. https://doi.org/10.1093/wber/15.2.177

Easterly, W., Micahel, K., Lant, P., \& Lawrence, H. S. (1993). Good Policy or Good Luck? 
Country Growth Performance and Temporary Shocks. Journal of Monetary Economics, 32, pp.459-483. https://doi.org/10.1016/0304-3932(93)90026-C

Ekpo, A. H. (2013). Rethinking Institutions and Economic Development: Is there a any Framework?" Being a paper presented at the 54th Annual Conference of the Nigerian Economic Society (NES), Abuja, Nigeria Sept, 17-19

Flachaire, E., García-Pe-alosa, C., \& Konte, M. (2014). Political versus Economic Institutions in the Growth Process. Journal of Comparative Economics, 42(1), 212-229, https://doi.org/10.1016/j.jce.2013.05.001

Fosu, A. K. (2013). Institutions and African Economies: An Overview. Journal of African Economies, 22(4), 491-498. https://doi.org/10.1093/jae/ejt016

García-Belenguer, F., \& Santos, M. S. (2013). Investment rates and the Aggregate Production Function. European Economic Review, 63, 150-169. https://doi.org/10.1016/j.euroecorev.2013.06.007

Gennaioli, N., La Portal, R., Florencio, Lopez-de-Silanes, \& Shleifer, A. (2014) Human Capital and Regional Development. Quarterly Journal of Economics, 128(1), 105-164. https://doi.org/10.1093/qje/qjs050

Guisan, Maria-Carmen. (2009). Government Effectiveness, Education, Economic Development and Well-Being: Analysis of European Countries in Comparison with the United States and Canada 2000-2007. Applied Econometrics and International Development, 9-1, 39-55.

ILO (2012) Global Employment Outlook: Bleak Labour Market Prospects for Youth. International Labour Organisation. September, 2012. www.ilo.org/publns

International Country Risk Guide (ICRG). (2014). Political Risk Guide. New York: PRS Group. http://www.prsgroup.com (accessed November 2014)

Isard, P. (2007). Equilibrium Exchange Rates: Assessment Methodologies. IMF Working Paper, WP/07/296. https://doi.org/10.5089/9781451868593.001

Jalilian, H., Kirkpatrick, C., \& Parker, D. (2006). The Impact of Regulation on Economic Growth in Developing Countries: A Cross-Country Analysis. World Development, 35(1), 87-103.

https://doi.org/10.1016/j.worlddev.2006.09.005

Jens A., Bassanini, A., \& Scarpetta S. (2011), Solow or Lucas? Testing speed of convergence on a panel of OECD countries. Research in Economics, 65, 110-123. https://doi.org/10.1016/j.rie.2010.11.005

Jorgenson, D. W., Frank, M. G., \& Babara, M. F. (1987). Prductivity and U.S. Economic Growth. Cambridge MA, Harvard University Press.

Kallon, M. K. (2013), Growth Empirics: Evidence from Sierra Leone. African Development 
Review, 25(2), 215-230, June 2013. https://doi.org/10.1111/j.1467-8268.2013.12025.x

Kaufmann, D., Aart, K., \& Massimo, M. (2009). Governance Matters VIII Aggregate and Individual Governance Indicators, 1996-2008. The World Bank Development Research Group Macroeconomics and Growth Team Policy Research, Working Paper, WPS4978. https://doi.org/10.1596/1813-9450-4978

Krugman, P. (1994). The Myth of Asias Miracle. Foreign Affairs, 73(6), 62-78. https://doi.org/10.2307/20046929

Kui-Wai, L., \& Xianbo, Z. (2011).Evidence Cross-country Convergence and Growth: from Nonparametric and Semiparametric Analysis. Paper submitted to APEC Study Center Consortium Conference September 22 - 23, 2011, San Francisco, USA

Leong, C. K. (2007). A Tale of Two Countries: Openness and Growth in China and India. Dynamics, Economic Growth and International Trade (DEGIT), Conference Paper, pp: 1-26.

Lipset, S. M. (1960) (1981). The Political Man: The Social bases of Politics. Baltimore, M.D:John Hopkins

Lucas, R. E. (1988). On the Mechanics of Economic Development. Journal of Monetary Economics, 22(3), 3-42. https://doi.org/10.1016/0304-3932(88)90168-7

Mahmud, H. (2009). Why Has Growth Slowed in Sub-Sahara Africa? A System IV-GMM Approach Economic and Financial Review. Central Bank of Nigeria Vol. 47, No. 3, Sept., 2009.

Mankiw, G. N., Romer, D., \& Weil, D. N., (1992). A Contribution to the Empirics of Economic Growth. Quarterly Journal of Economics, 107, 407-437. https://doi.org/10.2307/2118477

Martins, I., \& Olarinde, M. (2014). Impact of exchange rate depreciation on the balance of payments: Empirical evidence from Nigeria. Cogent Economics \& Finance, 2(1). https://doi.org/10.1080/23322039.2014.923323

Mbulawa, S. (2015). Determinants of Economic Growth in Southern Africa Development Community: The Role of Institutions. Applied Economics and Finance, 2(2). https://doi.org/10.11114/aef.v2i2.782

Narayan, P. K., \& Narayan, S. (2010). Carbon Dioxide Emissions and Economic Growth: Panel Data Evidence from Developing Countries. Energy Policy, 38(1), 661-666. https://doi.org/10.1016/j.enpol.2009.09.005

North, D. C. (1991): Institutions. The Journal of Economic Perspectives, 5(1), 97-112. https://doi.org/10.1257/jep.5.1.97

O'Connell, S. A., \& Ndulu B. J. (2000). Africa's Growth Experience: A Focus on Sources of Growth, Framework paper for the AERC Explaining African Economic Growth project: AERC Nairobi, Kenya. http://www.cid.harvard.edu/cidpeople/bates/research.htm 


\section{Macrothink}

Journal of Asian Development

ISSN 2377-9594

2019, Vol. 5, No. 2

Ouechtati, I., \& Zaouali, A. (2013). Comovements and Structural Factors of Macroeconomic Volatility in Developing and Transition Economies: A Dynamic Panel Data Approach. Asian Economic and Financial Review, 3(120, 1562-1582.

Owen A. L., Julio Videras et Lewis Davis (2009). Do all Countries Follow the Same Growth Process." Journal of Economic Growth, 14(4),December 2009. https://doi.org/10.1007/s10887-009-9046-X

Perman, R., \& Stern, D. I. (2003). Evidence from Panel Unit Root and Cointegration Tests that the Environmental Kuznets curve does not exist. Australian Journal of Agricultural and Resource Economics, 47(3), pp. 325-347. https://doi.org/10.1111/1467-8489.00216

Rebelo S. (1991). Long run Policy Analysis and Long Run Growth: Journal of Political Economy, 99, 500-521. https://doi.org/10.1086/261764

Rodrik, D. (2009). The Real Exchange Rate and Economic Growth. John F. Kennedy School of Government, Harvard University. September 2008. https://doi.org/10.1353/eca.0.0020

Romer P. M. (1986). Increasing Return to Scale and Long-run Growth. Journal of Political Economy, 94, 1002-37. https://doi.org/10.1086/261420

Romer P. M. (1991). Capital, Labour and Productivity. Brooking Papers on Economic Activity, Special Issue, 337-367. https://doi.org/10.2307/2534785

Ros J. (2013). Rethinking Economic Development, Growth and Institutions (1st ed.) Oxford, Oxford University Press

Sarwar Saima, M., Wasif, S., \& Abdul Rauf, B. (2013). Role of Institutions and Economic Growth in Asian Countries" Developing Country Studies, 3(2), 80-90.

Siddiqui, D. A., \& Ahmed, Q. M. (2009). The Causal Relationship between Institutions and Economic Growth: An Empirical Investigation for Pakistan Economy: MPRA Paper No. 19745.

Solow R. M. (1957). Technical Change and Aggregate Production Function. Review of Economics and Statistics, 39, 312-320. https://doi.org/10.2307/1926047

Stern, D. I., \& Cutler, J. C. (2004). Energy and Economic Growth, Rensselaer Polytechnic Institute, Working Paper in Economics No. 0410. Retrieved from http://www.rpi.edu/dept/economics/www/workingpapers

Temple J. R. W. (2001). Heterogeneity and the Growth Process Generalizations that Aren't? Evidence on Education and Growth. European Economic Review, 45, 905-918. https://doi.org/10.1016/S0014-2921(01)00116-7

Umoru, D., \& Matthew, I. E. (2013). Industrial Development and Trade Liberalisation In Nigeria: Is There A Significant Correlation?. Asian Journal of Empirical Research, 3(4), 493-509.

Utpal Kumar, De, \& Manoranjan, P. (2011). Dimensions of Globalisation and Their Effects 


\section{Macrothink}

Journal of Asian Development

ISSN 2377-9594 2019, Vol. 5, No. 2

on Economic Growth and Human Development Index. Asian Economic and Financial Review, 1(1), 1-13.

Wong, A., \& Zhou, X. (2011). Development Financial Markets and Economic Growth : Review of Hong Kong, China, Japan, USA and UK. International Journal of Economics and Finace, 111-116. https://doi.org/10.5539/ijef.v3n2p111

World Bank (2013). World Development Indicators. The World Bank, Washington DC. http://databank.worldbank.org/data/views/reports/tableview.aspx\#. Retrieved from the web on 15th August, 2013.

Young A. (1994). The Tyranny of Numbers: Confronting the Statistical Realities of the East Asian Growth Experience. Quarterly Journal of Economics, 110(3), 641-680. https://doi.org/10.3386/w4680

\section{Appendix I: List of Countries included in the Study}

\begin{tabular}{|c|c|c|c|}
\hline High Income & Upper Middle Income & Lower Middle Income & Low Income \\
\hline \multirow[t]{21}{*}{ Equatorial Guinea } & Botswana & Angola & Burundi \\
\hline & Mauritius & Lesotho & Comoros \\
\hline & Namibia & Zambia & Eritrea \\
\hline & South Africa & Mozambique & Ethiopia \\
\hline & Tunisia & Malawi & Kenya \\
\hline & Gabon & Zimbabwe & Madagascar \\
\hline & Algeria & & Rwanda \\
\hline & Libya & Cameroon & Somalia \\
\hline & & Congo Rep. & Tanzania \\
\hline & & Sao Tome Principe & Uganda \\
\hline & & Cote d 'Ivoire & Congo Dem. Rep. \\
\hline & & Cape Verde & Central African Rep. \\
\hline & & Ghana & Chad \\
\hline & & Nigeria & Benin \\
\hline & & Senegal & Burkina Faso \\
\hline & & Egypt & Guinea \\
\hline & & Morocco & Gambia \\
\hline & & Mauritania & Guinea-Bissau \\
\hline & & Sudan & Liberia \\
\hline & & & Mali \\
\hline & & & Niger \\
\hline
\end{tabular}


Sierra Leone

\begin{tabular}{lllll}
\hline Total & 01 & 08 & 18 & 23 \\
\hline
\end{tabular}

Source: UNECA, 2012.

\section{Copyright Disclaimer}

Copyright for this article is retained by the author(s), with first publication rights granted to the journal.

This is an open-access article distributed under the terms and conditions of the Creative Commons Attribution license (http://creativecommons.org/licenses/by/4.0/). 